\author{
S.D. Fazylov ${ }^{1 *}$, O.A. Nurkenov ${ }^{1,2}$, Z.M. Muldakhmetov ${ }^{1}$, A.M. Gazaliev ${ }^{1}$, \\ A.E. Arinova ${ }^{1,3}$, M.K. Ibraev ${ }^{2}$, L.M. Vlasova ${ }^{4}$, A.S. Fazylov ${ }^{2}$ \\ ${ }^{1}$ Institute of Organic Synthesis and Coal Chemistry of the Republic of Kazakhstan, Karaganda, Kazakhstan; \\ ${ }^{2}$ Karaganda State Technical University, Kazakhstan; \\ ${ }^{3}$ Karagandy University of the name of academician E.A. Buketov, Kazakhstan; \\ ${ }^{4}$ Karaganda Medical University, Kazakhstan \\ (Corresponding author's e-mail: iosu8990@mail.ru)
}

\title{
Biologically active derivatives of fullerene C60. Current state and development prospects
}

\begin{abstract}
The article presents literature review on the physicochemical and biological properties of fullerene C60, as well as the authors' own experimental data on the synthesis of fullerene derivatives of amines and natural alkaloids. It is shown that the presence of a fullerene fragment in the structure of the compound provides a significant improvement or the appearance of qualitatively new mechanical, chemical, physical, biological and other properties associated with the manifestation of nanoscale factors. The issues of the relationship of the structure, water solubility and biological activity of fullerene C60 derivatives are considered. Many biologically active effects of various modified derivatives of fullerene C60 are described, which have membrane-active, antibacterial, antiviral, immunomodulating, HIV inhibitory enzymes and other properties. It was noted that preparations containing a fullerene fragment are effective against hepatitis $\mathrm{C}$ virus, and are also able to efficiently trap free radicals. Derivatives of fullerenes can also be used as antioxidant, neuroprotective and other agents. Particular attention is paid to the authors' own results on the synthesis of amino derivatives of fullerenes.
\end{abstract}

Key words: fullerene C60, fulleropyrrolidines, nanoscale factors, amino fullerenes, Prato reaction.

\section{Introduction}

At present, in organic chemistry, fullerene bioorganic chemistry has acquired particular promise and is developing, turning abroad into an independent branch of organic chemistry. The presence of a fullerene fragment in the structure of the compound provides a significant improvement or the appearance of qualitatively new mechanical, chemical, physical, biological and other properties associated with the manifestation of nanoscale factors [1-3]. From a chemical point of view, the behavior of fullerenes defines the presence in the molecules of conjugated, and also strained, bonds. The spherical fullerene molecule is highly stressed, since usually flat six-membered aromatic (benzene) rings must be bent to build a sphere (voltage energy $\mathrm{dH}_{\mathrm{f}}=10.16 \mathrm{kcal} / \mathrm{mol}$ per carbon atom), which causes less thermodynamic stability of fullerene compared to graphite $\left(\mathrm{dH}_{\mathrm{f}}=0 \mathrm{kcal} / \mathrm{mol}\right)$ [2-4]. Therefore, the driving force of the reactions of addition to fullerene C60 is the reduction of voltage in the fullerene framework. Consequently, the reactions leading to the formation of saturated $\mathrm{sp}^{3}$-hybridized carbon atoms relieve such stress.

The range of possible applications of fullerene compounds includes: a) new classes of superconductors, semiconductors, magnets, ferroelectrics, nonlinear optical materials [4]; b) new technologies for the synthesis of diamonds and diamond-like compounds of ultrahard hardness [5]; c) new classes of polymers with specified mechanical, optical, electrical, magnetic properties for recording and storing information [6]; d) new types of catalysts and sensors for determining the composition of liquid and gaseous media [6]; e) new classes of antifriction coatings and lubricants, including those based on fluorine-containing fullerene compounds [7].

\section{Main part}

One of the most interesting areas of research is the study of the biological activity of fullerene derivatives. The literature describes many biologically active effects of various modified derivatives of fullerene C60, which have antibacterial [7], antiviral [1], immunomodulating and HIV inhibitory enzymes [6, 7]. Drags containing a fullerene fragment have been shown to be effective against hepatitis $\mathrm{C}$ virus [8], and are

${ }^{*}$ Corresponding author 
also able to efficiently trap free radicals and can be used as neuroprotective [9] and other agents [10]. Currently, the volume of work on the biological activity of fullerenes has reached thousands of articles per year. At this time available scientific data demonstrate the significant potential of fullerene $\mathrm{C} 60$ in biomedicine and the pharmacodynamics of various biological environments.

The biological effects of fullerene C60 are based on its complementary interaction with the protein, which was first expressed in $[1,3,10]$. The fullerene molecule has been shown to purely sterically block the lipophilic channel of the HIV-1 virus protease. The size and shape of the carbon skeleton in the C60 molecule exactly matches the size and shape of the active center of a number of enzymes. Therefore, some fullerene compounds allosterically inhibit HIV enzymes (HIV protease and reverse transcriptase), which makes them promising for the development of AIDS drugs [3-11]. The high electron deficiency of these molecules explains the ability of fullerenes to attach free radicals that form in living systems. For this property, fullerene was given the name «radical sponge» [7].

The biological activity of fullerenes is based on three properties of these molecules: lipophilicity, which determines membranotropic properties, electron deficiency, which leads to the ability to interact with free radicals, and the ability of their excited state to transfer energy to an ordinary oxygen molecule and turn it into singlet oxygen [7]. A significant limitation for the practical use of fullerenes and many of its derivatives in biological media is their low solubility in aqueous solutions, since the $\mathrm{C} 60$ molecule is hydrophobic and its solubility in water is only $1.310^{-11}$ [12]. Therefore, the preparation of water-soluble fullerenes is important for pharmacology. The study of the reactions of fullerenes in water is also of independent interest for chemical science. Researchers consider two approaches to obtaining water-soluble forms of fullerene C60:

1) non-covalent interaction with water-soluble carriers, for example, polyvinylpyrrolidone, cyclodextrins [3], proteins or liposomes [4];

2) covalent chemical modification by addition of polar groups, for example hydroxyl [4-14], carboxyl or amino groups $[3,4,15]$.

Non-covalent interaction with water-soluble carriers allows the introduction of fullerenes into a living organism without changing their conjugation system, and hence the physicochemical properties. Surfactant solutions can also conduct water-insoluble organic compounds into a colloidal state or solubilize. However, due to hydrophobicity, the problem arises of their elimination from the body: fullerenes can accumulate in the liver [16], lungs [17], bones [18].

The second approach allows one to obtain water-soluble fullerene derivatives by covalent modification of the fullerene sphere with various functional groups (addends) - dienes and nucleophilic agents having various hydrophilic components. Thus, various pharmacophore groups can be grafted onto fullerene C60 and additional physiological activity can also be obtained. The result of this modification is molecules that can conditionally be divided into two groups:

1) compounds in which addends uniformly cover the entire surface of the fullerene carcass, as a result of which numerous addends attached over the entire surface change the electronic structure of the carbon carcass and make it inaccessible for interaction with biological targets;

2) compounds having one or more addends grouped on a small part of the frame.

The latter option is most often used in the synthesis of potentially bioactive water-soluble fullerene cycloadducts. Several examples of such water-soluble fullerene derivatives can be given. For example, compound (1) allows reaching a maximum concentration of $1.5 \times 10^{-5} \mathrm{~mol} / 1$ in a mixture of $\mathrm{H}_{2} \mathrm{O}-\mathrm{DMSO}, 9: 1$ $[4,19]$. Good solubility was achieved for the dendromer shown in the diagram (2): its solubility in water was $34 \mathrm{mg} / \mathrm{ml}$ at $\mathrm{pH} 7.4$ and $254 \mathrm{mg} / \mathrm{ml}$ at $\mathrm{pH} 10[4,11]$. As can be seen from the structure of compounds (1) and (2), they contain a sufficient amount of solubilizing additions $(\mathrm{NH}, \mathrm{OH}, \mathrm{COOH}, \mathrm{C}=\mathrm{O}$-groups).

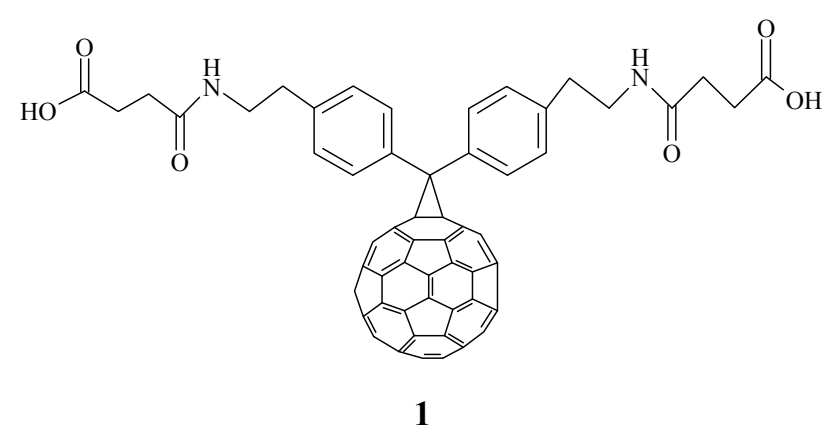




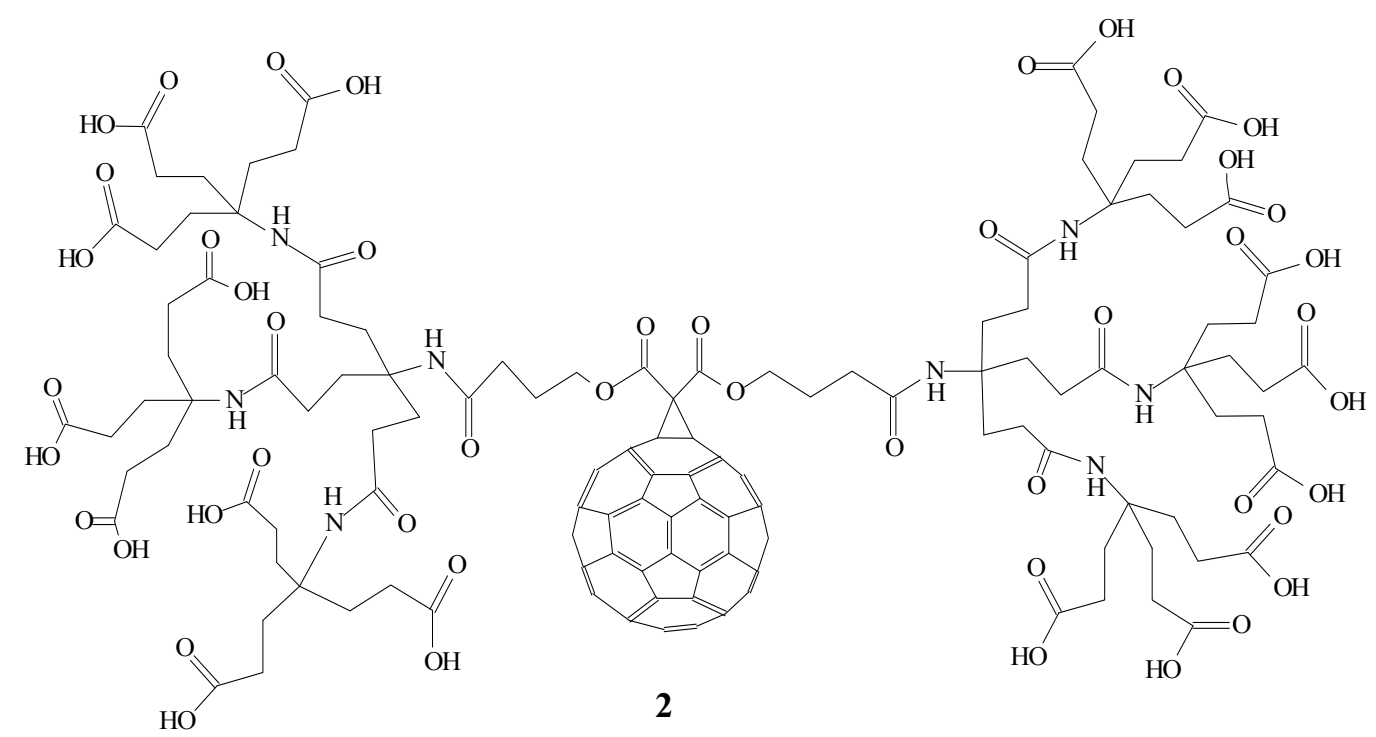

O.A. Troshina et al. [11] reported on the development of a universal method for the conversion of any low-polar derivatives of C60 into water-soluble compounds. The solubility of all the compounds obtained in water exceeds $100 \mathrm{mg} / \mathrm{ml}$ at $\mathrm{pH}=7.0$, which is a record for water-soluble derivatives of fullerenes. Thus, the introduction of hydrophilic substituents into the $\mathrm{C} 60$ sphere allows for sufficient solubility in water.

The most promising results in this direction were obtained using chemically modified fullerene C60, mainly containing ionic groups - amine, carboxyl and hydroxyl [7, 11].

Amino derivatives of fullerene. The reactions of addition of primary and secondary amines to C60 were one of the first to be discovered in the chemistry of fullerene. Due to their high nucleophilicity, primary and secondary aliphatic amines are attached to electron-deficient $\mathrm{C} 60$-fullerene.

When fullerene C60 is treated with a 40 -fold excess of morpholine over a week, it is possible to isolate dimorpholin-1,4-dihydro [C60] fullerene from the reaction medium (3). In contrast to the reaction with morpholine, the reaction with an excess of secondary diamine (e.g., N,N'-dimethylethylenediamine) leads to a stable six-membered adduct (4) due to the addition of a 6-6 double bond, which eliminates the formation of undesired 5-6 double bonds in the molecule, violating the aromaticity of six-membered rings [11].
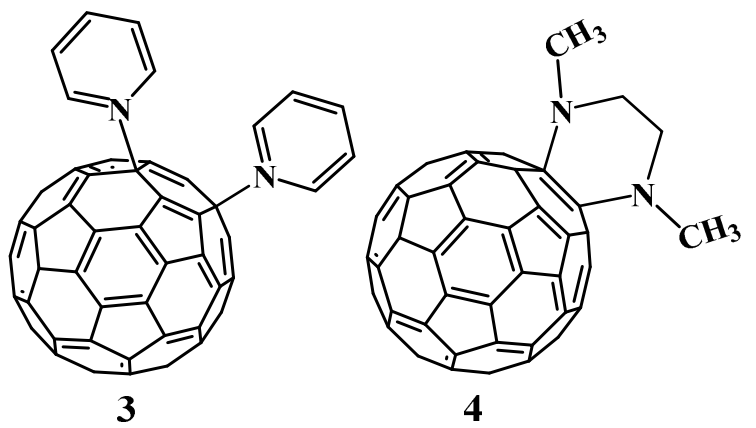

For several years, we have been working at the Institute of Organic Synthesis and Coal Chemistry of the Republic of Kazakhstan on the functionalization of the C60 molecule with the participation of molecules of various amines, including natural compounds (alkaloids) and their derivatives. This is an interesting direction that can lead to important results in terms of creating new therapeutic drugs.

We carried out the amination of fullerene C60 with 2-(aminomethyl)pyridine in middle chlorobenzene with heating $\left(80-100^{\circ} \mathrm{C}\right)$ and stirring for $18-24$ hours. The yield of obtained aminofullerene (5) was $19 \%$ [12-14]. UV spectrum of compound (5) contains a maximum at $\lambda=875 \mathrm{~nm}$, characteristic of 1,4-di[2(aminomethyl)pyridine]fullerene C60.

Similar syntheses were carried out with alkaloid cytisine and salsolin. The reactions were carried out in toluene at $100^{\circ} \mathrm{C}$ for $28-30$ hours. However, the isolation of $\mathrm{C} 60$ amination products with alkaloids was unsuccessful. 


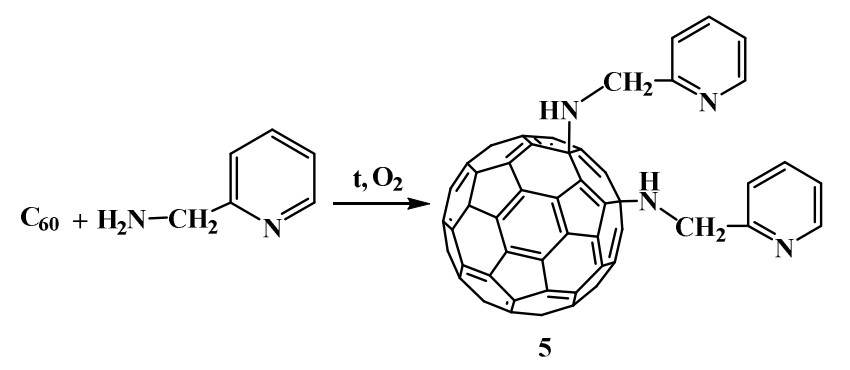

Among the most convenient methodologies for the functionalization of C60 by the amines described in recent years, the 1,3-dipolar azomethynilide cycloaddition is widely used, leading to the formation of fulleropyrrolidines. This method is based on the generation of azomethinilides during decarboxylation of the ammonium salts obtained by condensation of $\alpha$-amino acids with aldehydes. This method is called in the literature the Prato reaction [4, 8]. Following this technique, the synthesis of new fullerenepyrrolidines (6-12) was carried out, by the interaction of $\mathrm{C} 60$ fullerene with sarcosine and substituted aromatic aldehydes (4-fluorobenzaldehyde, 2-chlorobenzaldehyde, 2-hydroxy-5-bromobenzaldehyde, 4-morpholino-benzaldehyde, 4-piperidinediethylaminobenzaldehyde, 4-diethylamino-2-hydroxybenzaldehyde) in boiling toluene in argon atmosphere according to the following scheme [15-17]:

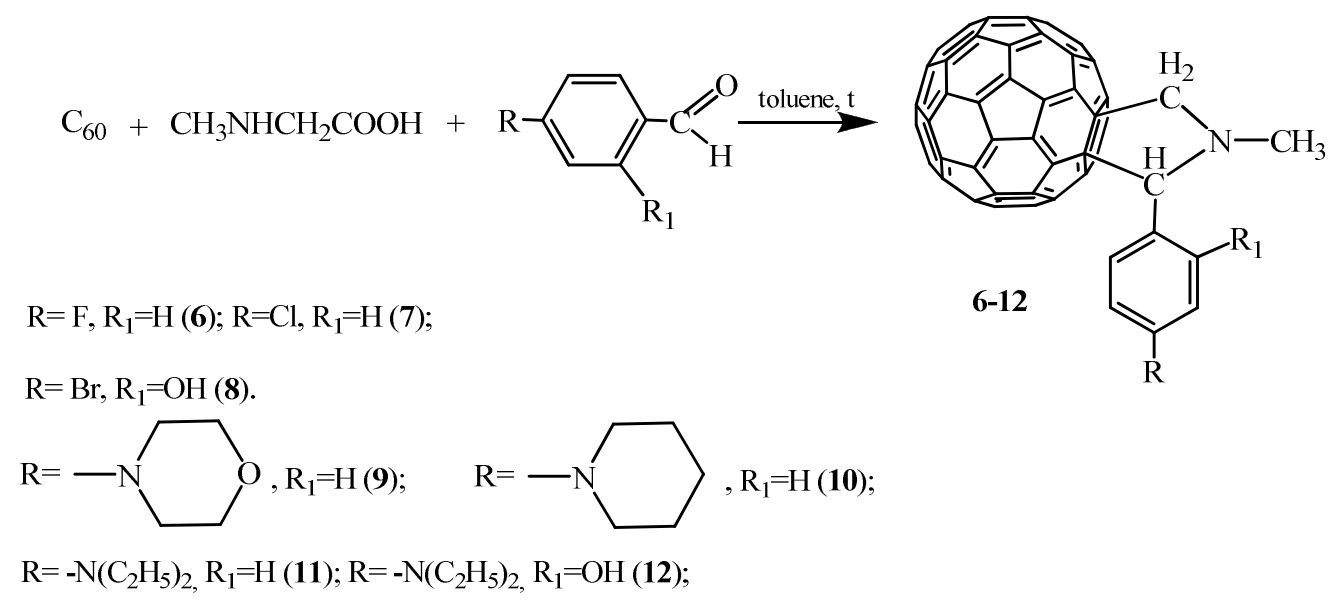

Unreacted starting materials and reaction products $(\mathbf{6}-\mathbf{1 2})$ after the reaction were separated by column chromatography on $\mathrm{SiO}_{2}$, eluting with toluene and then with pyridine. At the same time, at the beginning, the initial unreacted fullerene C60 is released, and then the target fulleropyrrolidines (4-10). The structure of the obtained compounds (6-12) was established by the data of IR, NMR ${ }^{1} \mathrm{H}$, and $\mathrm{H}-{ }^{1} \mathrm{H}$ NOESY spectroscopy and mass spectrometry.

The Prato method considered above was used by us in the synthesis of new derivatives of fullerene C60 with alkaloids. To involve the alkaloid molecule in the reaction, we obtained 4-cytisinobenzaldehyde, which was then used in the Prato reaction in boiling toluene according to the following scheme $[15,16]$ :

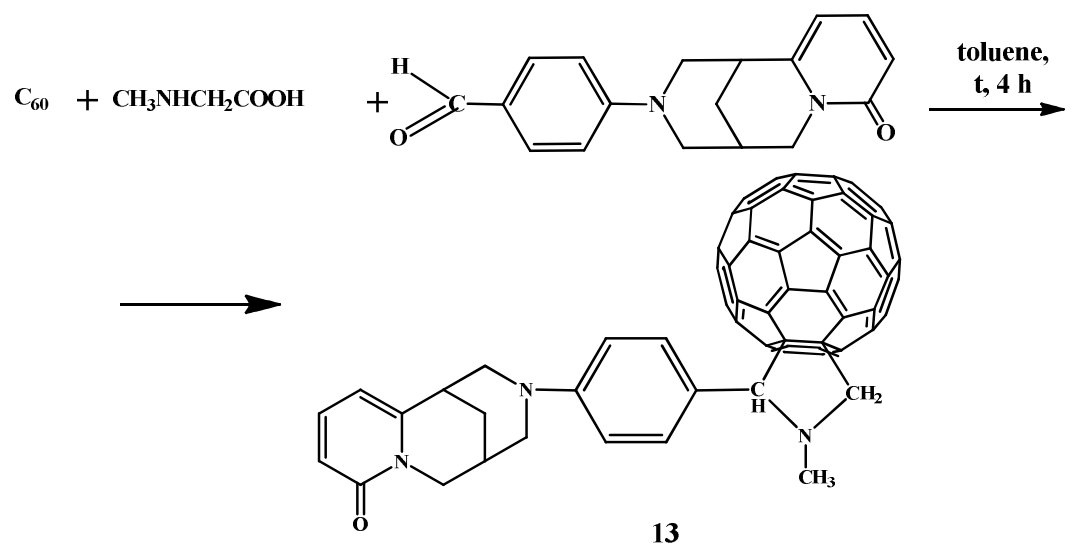


In order to expand the arsenal of new fulleropyrrolidines, we carried out a three-component condensation of fullerene C60, N-methylglycine (sarcosine) and new substituted benzaldehydes: [4-(oxiran-2ylmethoxy)benzaldehyde, 4-(2-hydroxy-3-morpholinopropoxy)benzaldehyde and 4-(2-hydroxy-3-cytisinopropoxy)benzaldehyde] under the conditions of the Prato reaction in toluene [15-17].

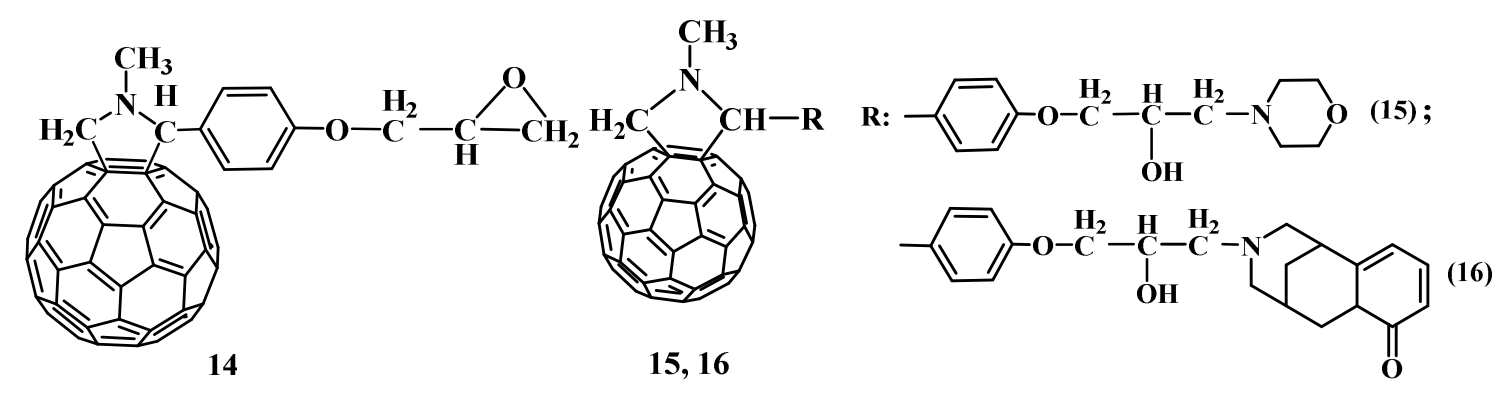

The synthesized fulleropyrrolidines (14-16) are of interest as acceptor materials for organic solar cells. A signal (2.67-2.80 ppm) of the methyl group is observed in the ${ }^{1} \mathrm{H}$ NMR spectrum of compounds (14-16) in the high-field region. Signals at 2.59 and $3.77 \mathrm{ppm}$ correspond to the protons of the methylene and methine groups of the nitrogenous heterocycle. The protons of the ethylene oxide (oxirane) link in (14) resonate at 2.87 and $3.5 \mathrm{ppm}$. In the high frequency region $(6.95-7.85 \mathrm{ppm})$, the symmetric protons of the aromatic system resonate. In addition to the indicated resonance lines, the signals of impurity substances are also observed in the ${ }^{1} \mathrm{H}$ NMR spectra.

To obtain water-soluble forms of the fullerene-containing pyrrolidines synthesized above, N-methyl-1[(4-diethylaminophenyl]-fullerene-C60-[1,9c]-pyrrolidine (11) and N-methyl-1-[(4-diethylamino-2-hydroxyphenyl]-fullerene-C60-[1.9c]-pyrrolidine (12) carried out reactions with tartaric acid to form the corresponding pyrrolidinium tartrates $(\mathbf{1 7}, \mathbf{1 8})$. The resulting fulleropyrrolidinium tartrates $(\mathbf{1 7}, \mathbf{1 8})$ are soluble in waterdimethyl sulfoxide (3:1) in contrast to the starting fulleropyrrolidines [15-17].

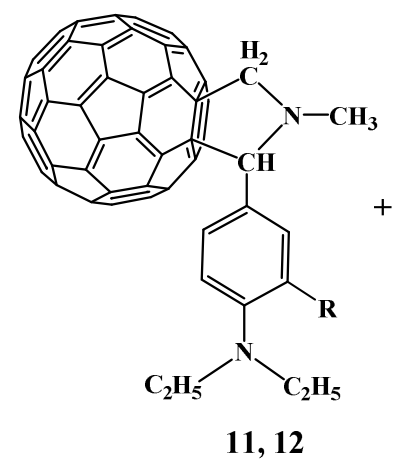

$\mathbf{R}=\mathbf{H}(11,17) ; \mathbf{R}=\mathbf{H}(12,18)$

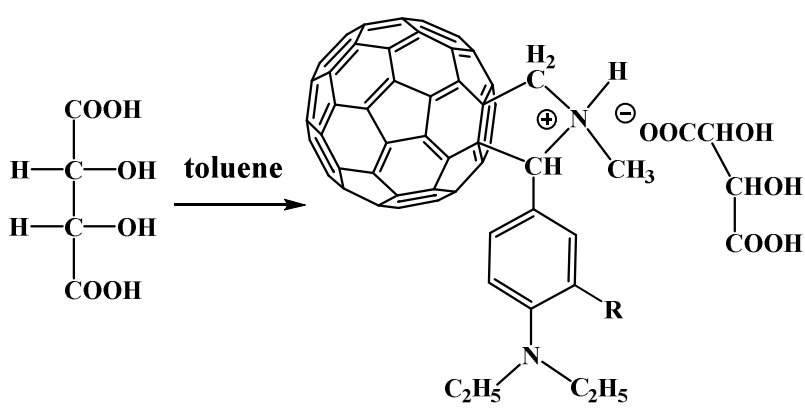

17,18

An interesting reaction for the preparation of a water-soluble cyclodextrin derivative of triazolino fullerene is described in $[18,19]$. The formation of supramolecular complexes based on fullerenes (19) with therapeutic agents can improve the bioavailability and pharmacokinetics of the latter, which opens the way to the creation of targeted drug delivery systems.<smiles>CNCC(=O)O</smiles> 


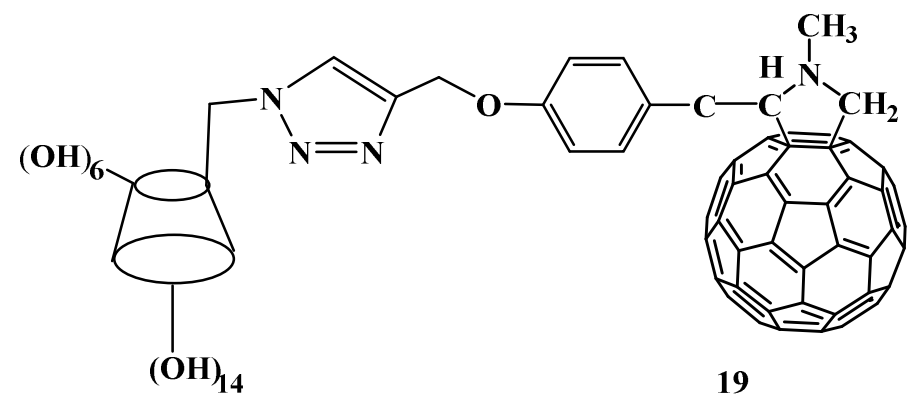

Fullerenols. An important group of water-soluble derivatives of fullerene C60 are fullerenols. By this term «fullerenol» («fullerol») is meant derivatives of fullerene $\mathrm{C} 60$ of composition $\mathrm{C} 60(\mathrm{OH})_{x}$. Hydroxylatedfullerenols are also of great interest in the search for possible applications in medicine. There are several methods for the synthesis of fullerenols with a different number of hydroxyl groups [7].

For example, hydrolysis of the ether functional groups of polyorganocarboxylated fullerene derivatives yielded water-soluble fullerenols $\mathrm{C} 60(\mathrm{OH})_{n}$ with 18-20 hydroxyl groups [13].

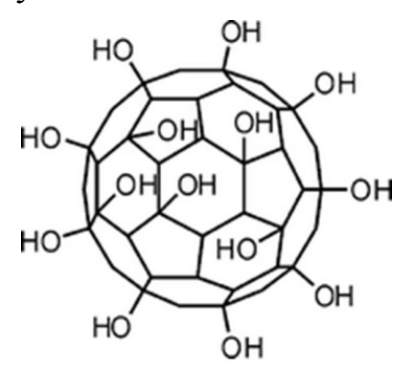

They have antioxidant properties, anticancer and antiviral activity, are able to prevent ischemia, which is caused by a sharp increase in ROS with energy depletion of organs and tissues [14]. Fullerenol $\mathrm{C} 60(\mathrm{OH})_{24}$ has antiproliferative properties (prevents cell division) and, due to its ability to attach free radicals, prevents the cytotoxic effects of the use of doxorubicin used in cancer chemotherapy [18-20].

Fullerenols $\mathrm{C} 60(\mathrm{OH})_{44}$ possess antibacterial and antifungal activity [19]. The antifungal activity of fullerenols is quite high. It seems that fullerenols are capable of interacting with carbohydrate components of fungal cell walls, such as $\beta$-glucan and chitin, to a greater extent than with peptidoglycans of bacterial cell membranes. Among fullerenols, substances with anti-allergic properties have also been found [20].

Carboxylated derivatives of fullerenes. Another important group of fullerenes with important biological properties is its carboxylated derivatives. For example, they can suppress neuronal apoptosis caused by glutamate receptor agonists NMDA and AMPA, and neutralize the action of the amyloid peptide responsible for the occurrence of Alzheimer's disease [7, 21-23].

They delay the development of functional impairment and death of the rats having the mutant human SOD gene. Also, these compounds are able to bind superoxide anion and $\mathrm{H}_{2} \mathrm{O}_{2}$, are effective inhibitors of lipid peroxidation. It was found that when introduced into the lateral ventricles of the brain, carboxyfullerene can eliminate the effects of oxidative damage caused by reperfusion ischemia [7, 18].

Aminacid derivatives of fullerenes. The synthesis of water-soluble derivatives of C60 fullerene with sodium salts of aminobutyric and $\varepsilon$-aminocaproic acids, as well as hybrid structures based on the fullerene derivative with proline and carnosine ( $\beta$-alanyl-L-histidine) are described [19-23, 24]. The considered derivatives possessed antioxidant activity. For the first time, the authors found a relationship between the suppression of the development of cytomegalovirus infection (CMVI) and the activation of peroxidation of lipid. Moreover, an effective inhibitor of CMVI from the class of amino acid derivatives of fullerene was obtained [23, 25-28]. Antiviral activity was also found in fullerene - (tris-aminocaproic acid) hydrate in non-toxic concentrations (up to $100 \mu \mathrm{g} / \mathrm{ml}$ ) with respect to the respiratory syncytial virus. The antiviral agent is offered as a $1 \%$ ointment of fullerene hydropolyaminocaproic acid as an active substance.

\section{Conclusions}

Thus, an analysis of the literature on the study of C60 fullerene derivatives allows us to draw the following conclusions about the current state of research in this area:

a) The uniqueness of fullerenes as a class of chemical compounds is determined by the peculiarities of their structure. They attract the attention of researchers for their practical applications in science, biology and medicine, in semiconductor technology and nanoelectronics.

b) Fullerenes have an unusually large number of equivalent reaction centers (in terms of the number of double bonds), which leads to the possibility of the formation of a large number of reaction products during 
the functionalization of their structure. Thus, most chemical reactions with fullerenes are not selective, which complicates the synthesis of individual compounds.

c) Most of the syntheses of derivatives of fullerenes described in the literature relate to the modification of fullerene C60. The data on the biological activity of fullerene derivatives presented in the literature are incomplete and fragmentary. In many works, the molecular mechanism of its manifestation has not been reliably established.

d) The most important properties of the structure of C60, affecting the spectrum of its biological action, are lipophilicity, membranotropicity and water solubility of its derivatives. The size, shape and high lipophilicity of fullerene allow its molecule to quite easily penetrate into cells of a living organism.

e) The formation of supramolecular complexes and therapeutic agents can improve the bioavailability and pharmacokinetics of the latter, which opens the way to the creation of targeted drug delivery systems.

\section{References}

1 Dumpis M.A. Biological activity of fullerenes - reality and prospects / M.A. Dumpis, D.N. Nikolaev, E.V. Litasova, V.V. Iljin, M.A. Brusina, L.B. Piotrovsky // Reviews on Clinical Pharmacology and Drug Therapy. — 2018. — Vol. 16. — P. 4-20. DOI: 10.17816/RCF1614-20.

2 Petrone L. Recombinant HPV16 E7 assembled into particles induces an immune response and specific tumour protection administered without adjuvant in an animal model / L. Petrone, M.G. Ammendolia, A. Cesolini, S. Caimi, F. Superti, C. Giorgi, P. Di Bonito // J. Transl. Med. - 2011. - No. 9. - P. 2-9.

3 Penkova A.V. Fullerene derivatives as nano-additives in polymer composites / A.V. Penkova, S.F. Acquah, L.B. Piotrovskiy, D.A. Markelov, A.S. Semisalova, H.W. Kroto // Russ. Chem. Rev. - 2017. - Vol. 86, No. 6. - P. 530-566. DOI: 10.1070/RCR4712.

4 Piotrovsky L.B. Fullerenes and Viruses / L.B. Piotrovsky, O.I. Kiselev // Fullerenes, Nanotubes and Carbon Nanostructures. - 2005. - Vol. 12, No. 1-2. - P. 397-403. DOI: 10.1081/fst-120027198.

5 Bosi S. Fullerene derivatives: an attractive tool for biological applications / S. Bosi, T. Da Ros, G. Spalluto, M. Prato // Eur. J. Med. Chem. — 2003. - Vol. 38, No. 11-12. — P. 913-923. DOI: 10.1016/j.ejmech.2003.09.005.

6 Ikeda A. Cyclodextrin complexed [60] fullerene derivatives with high levels of photodynamic activity by long wavelength excitation / A. Ikeda, T. Iizuka, N. Maekubo // ACS medicinal chemistry letters. — 2013. — Vol. 4, No. 8. — P. $752-756$. DOI:10.1007/s10847-013-0319-9.

7 Mizuno K. Antimicrobial Photodynamic Therapy with Functionalized Fullerenes: Quantitative Structure-activity Relationships / K. Mizuno, T. Zhiyentayev, L. Huang, S. Khalil, F. Nasim, G.P. Tegos, H. Gali, A. Jahnke, T. Wharton, M.R. Hamblin // J. Nanomed. Nanotechnol. — 2011. - Vol. 2, No. 2. - P. 100109-100117. DOI: 10.4172/2157-7439.1000109.

8 Komatsu T. Structural and mutagenic approach to create human serum albumin-based oxygen carrier and photosensitizer / T. Komatsu, A. Nakagawa, X. Qu. // Drug metabolism and pharmacokinetics. — 2009. — Vol. 24, No. 4. — P. $287-299$.

9 Bogdanovic V. Fullerenol $\mathrm{C}_{60}(\mathrm{OH})_{24}$ effects on antioxidative enzymes activity in irradiated human erythroleukemia cell line / V. Bogdanovic, K. Stankov, I. Icevic, D. Zikic, A. Nikolic // Journal of radiation research. — 2008. — Vol. 49, No. 3. — P. 321327.

10 Трошина О.А. Водорастворимые производные фуллеренов - потенциальные медицинские препараты / О.А. Трошина, Р.А. Трошин, А.С. Перегудов, Р.К. Любовская // Журн. инновации. — 2007. — № 5. — C. 105. ISSN: 20713010 .

11 Bhoi V.I. The self-assembly and aqueous solubilization of $\lceil 60\rceil$ fullerene with disaccharides / V.I. Bhoi, S. Kumar, C.N. Murthy // Carbohydr. Res. — 2012. — Vol. 359. — P. 120-127. DOI: 10.1016/j.carres.2012.07.010.

12 Bosi S. Synthesis and water solubility of novel fullerene bisadduct derivatives / S. Bosi, L. Feruglio, D. Milic, M. Prato // Eur. J. Org. Chem. — 2003. - P. 4741-4747. DOI:10.1002/ejoc. 200300494.

13 Fazylov S.D. Synthesis and structure of N-methyl-1-phenylfullereno-C-60[1,9]pyrrolidines based on aminoaldehydes / S.D. Fazylov, O.A. Nurkenov, A.E. Arinova, A.P. Tyktarov, A.A. Khuzin, K.M. Turdybekov // Journal of General Chemistry. 2014. - Vol. 84, No. 10. — P. 2058-2059. DOI: 10.1134/S1070363214100375.

14 Fazylov S.D. Synthesis and Structure of N-methyl-1-[(4-bromo-3,5-dime-thyl-1H-pyrazol-1-yl)phenyl]fullerene-C60「1,9-c]pyrrolidine / S.D. Fazylov, O.A. Nurkenov, A.E. Arinova, T.M. Seilkhanov, A.R. Tuktarov, A.A. Khuzin, R.E. Bakirova, L.E. Muravleva // Russian Journal of General Chemistry. — 2015. - Vol.85, No.5. — P. $1049-1051$. DOI: $10.1134 /$ S1070363215050072.

15 Roy P. Exploring the inhibitory and antioxidant effects of fullerene and fullerenol on ribonuclease A. / P. Roy, S. Bag, D. Chakraborty, S. Dasgupta // ACS Omega. — 2018. - Vol. 3, No. 9. - P. 12270-12283. DOI: 10.1021/acsomega.8b01584.

$16 \mathrm{Hu}$ Z. Photodynamic anticancer activities of water-soluble C60 derivatives and their biological consequences in a HeLa cell line / Z. Hu, C. Zhang, Y. Huang // Chemico-biological interactions. - 2012. - Vol. 195, No. 1. - P. 86-94.

$17 \mathrm{Xu}$ J.-Y. Protective effects of fullerenol on carbon tetrachloride-induced acute hepatotoxicity and nephrotoxicity in rats / J.-Y. Xu, Y.-Y. Su, J.-S. Cheng // Carbon. — 2010. — Vol. 48, No. 5. — P. 1388-1396.

18 Jiao F. Studies on anti-tumor and antimetastatic activities of fullerenol in a mouse breast cancer model / F. Jiao, Y. Liu, Y. Qu // Carbon. - 2010. - V. 48, No. 8. - P. 2231-2243.

19 Djordjevic A. Antioxidant properties and hypothetical radical mechanism of fullerol $\mathrm{C}_{60}(\mathrm{OH})_{24} /$ A. Djordjevic, J. Canadanovic-Brunet, M. Vojinovic Miloradov // OxidCommun. — 2005. — Vol. 27, No. 4. — P. 806-812. 
20 Injac R. Acute doxorubicin pulmotoxicity in rats with malignant neoplasm is effectively treated with fullerenol $\mathrm{C}_{60}(\mathrm{OH})_{24}$ through inhibition of oxidative stress / R. Injac, N. Radic, B. Govedarica // Pharmacological Reports. — 2009. - Vol. 61, No. 2. P. 335-342.

21 Jiang G. Synthesis and properties of novel water-soluble fullerene-glycine derivatives as new materials for cancer therapy / G. Jiang, F. Yin, J. Duan, G. Li // J. Mater. Sci: Mater. Med. - 2015. — Vol. 26. — P. 1-7. DOI: 10.1007/s10856-014-5348-4.

$22 \mathrm{Hu}$ Z. Photodynamic anticancer activities of water-soluble C60 derivatives and their biological consequences in a HeLa cell line / Z. Hu, C. Zhang, Y. Huang // Chemico-biological interactions. - 2012. - Vol. 195, No. 1. - P. 86-94. DOI: 10.1016/j.carbon.2007.10.041.

23 Kotelnikova R.A. Antioxidant properties of water-soluble amino acid derivatives of fullerenes and their role in the inhibition of herpes virus infection / R.A. Kotelnikova, A.V. Smolina, V.V. Grigoryev, I.I. Faingold, D.V. Mishchenko, D.A. Poletaeva // Rus. Chem. Bull. — 2011. — Vol. 6. — P. 1172-1176. DOI: 10.1039/ C4MD00194J.

24 Fazylov S.D. Synthesis of New Chromene-Containing Fulleropyrrolidines / S.D. Fazylov, O.A. Nurkenov, A.E. Arinova, T.M. Seilkhanov, M.K. Ibraev, E.M. Tazhbaev // Journal of General Chemistry. — 2020. — Vol. 90, No. 7. — P. $1143-1145$.

25 Teradal N.L. Carbon Nanomaterials in Biological Studies and Biomedicine / N.L. Teradal, R. Jelinek // Adv Healthc Mater. — 2017. — Vol. 6(17). — P. 1700574. DOI: 10.1002/adhm.201700574.

26 Ilyin V.V. The study of the stability of fullerene C60 films / V.V. Ilyin, L.B. Piotrovskii // Reviews on Clinical Pharmacology and Drug Therapy. - 2017. - Vol. 15, No. 2. - P. 42-45.

27 Misra C. Glycinated fullerenes for tamoxifen intracellular delivery with improved anticancer activity and pharmacokinetics / C. Misra, M. Kumar, G. Sharma // Nanomedicine (Lond). - 2017. — Vol. 12, No. 9. - P. 1011-1023. DOI: 10.2217/nnm-0432.

28 Ikeda A. Improved photodynamic activities of liposome-incorporated [60]fullerene derivatives bearing a polar group / A. Ikeda, T. Mae, M. Ueda // Chem Commun (Camb). — 2017. — Vol. 53, No. 20. - P. 2966-2969. DOI: 10.1039/c7cc00302a.

\author{
С.Д. Фазылов, О.А. Нүркенов, З.М. Молдахметов, А.М. Ғазалиев, \\ А.Е. Аринова, М.К. Ибраев, Л.М. Власова, А.С. Фазылов
}

\title{
Фуллерен С60 биологиялық белсенді туындылары. Казіргі заманғы жағдайы мен даму болашағы
}

\begin{abstract}
Мақалада С60 фуллереннің ғылыми әдебиеттердегі физикалық-химиялық және биологиялық қасиеттері туралы, сонымен бірге мақала авторларының аминдер мен табиғи алкалоидтарының фуллеренді туындыларын синтездеу реакцияларын зерттеу нәтижелері келтірілген. Заттардың құрылысында фуллеренді фрагменттің болуы оларға жаңа сапалы механикалық, физикалық, химиялық, биологиялық және басқа да қасиеттер әкелетіні наномасштабтық факторлардың пайда болуымен көрсетілген. С60 фуллеренді туындылардың биологиялық қасиеттерінің, құрылысының және суда ерігіштігінің арасындағы байланыс сұрақтары қарастырылған. Фуллерен С60 көптеген мембранотропты, бактериялық, вирустарға қарсы, иммунды түрлендірушілік, АҚТҚ тежеушілік және тағы да басқа қасиеттері бар көптеген түрлендірілген туындыларының биологиялық белсенділік әсерлері зерттелген. Құрамында фуллерені бар препараттардың гепатит С вирусына қарсы, сонымен бірге олардың бос радикалдарды ұстап алу қасиеттері өте жоғары. Фуллерендердің туындыларының сондай-ақ нейротроптылық пен антиоксиданттылық және басқа да тиімді әсерлері бар екені көрсетілген. Мақала авторларының фуллереннің аминотуындыларын синтездеу жұмыстары нәтижелеріне де аса көп көңіл бөлінген.
\end{abstract}

Кілт сөздер: фуллерен С60, фуллеропирролидиндер, наномасштабты факторлар, аминді фуллерендер, Прато реакциясы.

\author{
С.Д. Фазылов, О.А. Нуркенов, 3.М. Мулдахметов, А.М. Газалиев, \\ А.Е. Аринова, М.К. Ибраев, Л.М. Власова, А.С. Фазылов
}

\section{Биологически активные производные фуллерена С60. Современное состояние и перспективы развития}

В статье представлен обзор литературы о физико-химических и биологических свойствах фуллерена C60, а также даны собственные экспериментальные данные авторов по синтезу фуллереновых производных аминов и природных алкалоидов. Показано, что наличие фрагмента фуллерена в структуре соединения обеспечивает значительное улучшение или появление качественно новых механических, химических, физических, биологических и других свойств, связанных с проявлением наноразмерных факторов. Рассмотрены вопросы взаимосвязи структуры, растворимости в воде и биологической активности производных фуллерена С60. Описано множество биологически активных эффектов различных модифицированных производных фуллерена С60, которые обладают мембранотропными, антибактериальными, противовирусными, иммуномодулирующими, ингибирующими ВИЧ ферментными 
и другими свойствами. Было отмечено, что препараты, содержащие фрагмент фуллерена, эффективны против вируса гепатита $\mathrm{C}$, а также способны улавливать свободные радикалы. Производные фуллеренов также могут использоваться в качестве антиоксидантных, нейропротекторных и других средств. Особое внимание уделено собственным результатам авторов по синтезу аминопроизводных фуллеренов.

Ключевые слова: фуллерен С60, фуллеропирролидины, наноразмерные факторы, аминопроизводные фуллеренов, реакция Прато.

\section{References}

1 Dumpis, M.A., Nikolaev, D.N., Litasova, E.V., Iljin, V.V., Brusina, M.A., \& Piotrovsky, L.B. (2018). Biological activity of fullerenes - reality and prospects. Reviews on Clinical Pharmacology and Drug Therapy, 16, 4-20.

2 Petrone, L. Ammendolia, M.G., Cesolini, A., Caimi, S., Superti, F., Giorgi, C., \& Bonito, P. Di. (2011). Recombinant HPV16 E7 assembled into particles induces an immune response and specific tumour protection administered without adjuvant in an animal model. J. Transl. Med., 9, 2-9.

3 Penkova, A.V., Acquah, S.F., Piotrovskiy, L.B., Markelov, D.A., Semisalova, A.S., \& Kroto, H.W. (2017). Fullerene derivatives as nano-additives in polymer composites. Russ. Chem. Rev., 86(6), 530-566.

4 Piotrovsky, L.B., \& Kiselev, O.I. (2005). Fullerenes and Viruses. Fullerenes, Nanotubes and Carbon Nanostructures, 12(12), 397-403.

5 Bosi, S., Da Ros, T., Spalluto, G., Prato, M. (2003). Fullerene derivatives: an attractive tool for biological applications. Eur. J. Med. Chem., 38(11-12), 913-923.

6 Ikeda, A., Iizuka, T., Maekubo, N. (2013). Cyclodextrin complexed [60] fullerene derivatives with high levels of photodynamic activity by long wavelength excitation. ACS medicinal chemistry letters, 4(8), 752-756.

7 Mizuno, K., Zhiyentayev, T., Huang, L., Khalil, S., Nasim, F., \& Tegos, G.P., et al. (2011). Antimicrobial Photodynamic Therapy with Functionalized Fullerenes: Quantitative Structure-activity Relationships. J. Nanomed. Nanotechnol., (2)2, 100109100117.

8 Komatsu, T., Nakagawa, A., \& Qu., X. (2009). Structural and mutagenic approach to create human serum albumin-based oxygen carrier and photosensitizer. Drug metabolism and pharmacokinetics, 24(4), 287-299.

9 Bogdanovic, V., Stankov, K., Icevic, I., Zikic, D., \& Nikolic, A. (2008). Fullerenol $\mathrm{C}_{60}(\mathrm{OH})_{24}$ effects on antioxidative enzymes activity in irradiated human erythroleukemia cell line. Journal of radiation research, 49(3), 321-327.

10 Troshina, O.A., Troshin, R.A., Peregudov, A.S., \& Liubovskaia, R.K. (2007). Vodorastvorimye proizvodnye fullerenov potentsialnye meditsinskie preparaty [Water Soluble Derivatives of Fullerenes — Potential Medicines]. Zhurnal innovatsii - Innovation Magazine, 5, 105 [in Russian].

11 Bhoi, V.I., Kumar, S., \& Murthy, C.N. (2012). The self-assembly and aqueous solubilization of [60]fullerene with disaccharides. Carbohydr, 359, 120-127.

12 Bosi, S., Feruglio, L., Milic, D., \& Prato, M. (2003). Synthesis and water solubility of novel fullerene bisadduct derivatives. Eur. J. Org. Chem., 23, 4741-4747.

13 Fazylov, S.D., Nurkenov, O.A., Arinova, A.E., Tyktarov, A.P., Khuzin, A.A., \& Turdybekov, K.M. (2014). Synthesis and structure of N-methyl-1-phenylfullereno-C-60[1,9]pyrrolidines based on aminoaldehydes. Journal of General Chemistry, 84(10), 2058-2059.

14 Fazylov, S.D., Nurkenov, O.A., Arinova, A.E., Seilkhanov, T.M., Tuktarov, A.R., \& Khuzin, A.A., et al. (2015). Synthesis and structure of N-methyl-1-[(4-bromo-3,5-dime-thyl-1H-pyrazol-1-yl)phenyl] fullerene-C60-[1,9-c]pyrrolidine. Russian Journal of General Chemistry, 85(5), 1049-1051.

15 Roy, P., Bag, S., Chakraborty, D., \& Dasgupta, S. (2018). Exploring the inhibitory and antioxidant effects of fullerene and fullerenol on ribonuclease A. ACS Omega, 3(9), 12270-12283.

16 Hu, Z., Zhang, C., \& Huang, Y. (2012). Photodynamic anticancer activities of water-soluble C60 derivatives and their biological consequences in a HeLa cell line. Chemico-biological interactions, 195(1), 86-94.

17 Xu, J.-Y., Su, Y.-Y., \& Cheng, J.-S. (2010). Protective effects of fullerenol on carbon tetrachloride-induced acute hepatotoxicity and nephrotoxicity in rats. Carbon, 48(5), 1388-1396.

18 Jiao, F., Liu, Y., \& Qu, Y. (2010). Studies on anti-tumor and antimetastatic activities of fullerenol in a mouse breast cancer model. Carbon, 48(8), 2231-2243.

19 Djordjevic, A., Canadanovic-Brunet, J., \& Vojinovic Miloradov, M. (2005). Antioxidant properties and hypothetical radical mechanism of fullerol $\mathrm{C} 60(\mathrm{OH})_{24}$. OxidCommun., 27(4), 806-812.

20 Injac, R., Radic, N., \& Govedarica, B. (2009) Acute doxorubicin pulmotoxicity in rats with malignant neoplasm is effectively treated with fullerenol $\mathrm{C} 60(\mathrm{OH})_{24}$ through inhibition of oxidative stress. Pharmacological Reports, 61(2), 335-342.

21 Jiang, G., Yin, F., Duan, J., \& Li, G. (2015). Synthesis and properties of novel water-soluble fullerene-glycine derivatives as new materials for cancer therapy. J. Mater. Sci: Mater. Med., 26, 1-7.

$22 \mathrm{Hu}$, Z., Zhang, C., \& Huang, Y. (2012). Photodynamic anticancer activities of water-soluble C60 derivatives and their biological consequences in a HeLa cell line. Chemico-biological interactions, 195(1), 86-94.

23 Kotelnikova, R.A., Smolina, A.V., Grigoryev, V.V., Faingold, I.I., Mishchenko, D.V., \& Poletaeva, D.A. (2011) Antioxidant properties of water-soluble amino acid derivatives of fullerenes and their role in the inhibition of herpes virus infection. Rus. Chem. Bull., 6, 1172-1176. 
24 Fazylov, S.D., Nurkenov, O.A., Arinova, A.E., Seilkhanov, T.M., Ibraev, M.K., \& Tazhbaev, E.M. (2020) Synthesis of New Chromene-Containing Fulleropyrrolidines. Journal of General Chemistry, 90(7), 1143-1145.

25 Teradal, N.L., \& Jelinek, R. (2017). Carbon Nanomaterials in Biological Studies and Biomedicine. Adv Healthc Mater., 6(17), 1700574.

26 Ilyin, V.V., \& Piotrovskii, L.B. (2017). The study of the stability of fullerene C60 films. Reviews on Clinical Pharmacology and Drug Therapy, 15(2), 42-45.

27 Misra, C., Kumar, M., Sharma, G. (2017). Glycinated fullerenes for tamoxifen intracellular delivery with improved anticancer activity and pharmacokinetics. Nanomedicine (Lond), 12(9), 1011-1023.

28 Ikeda, A., Mae, T., \& Ueda, M. (2017). Improved photodynamic activities of liposome-incorporated [60]fullerene derivatives bearing a polar group. Chem Commun (Camb)., 53(20), 2966-2969. 